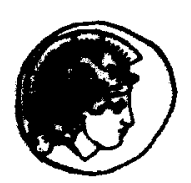

PERGAMON

Renewable Energy 16 (1999) 731--734

iandinge

Initivi

PERGAMON

\title{
INTEGRAL-TYPE SOLAR-ASSISTED HEAT PUMP WATER HEATER
}

\author{
B.J. Huang and J.P. Chyng \\ Department of Mechanical Engineering, National Taiwan University \\ Taipei, TAIWAN
}

\begin{abstract}
An integral-type solar-assisted heat pump water heater (ISAHP) is designed and tested in the present study. The storage tank and the Rankine cycle unit are integrated together to make a more compact size. A thermosyphon loop is used to transfer the heat from the condenser to the water storage tank. The highest COP obtained in the tests is 3.83. (C) 1998 Published by Elsevier Science L.td. All rights reserved.
\end{abstract}

\section{KEYWORDS}

Solar Energy; solar thermal; heat pump

\section{INTRODUCTION}

During 1987-1992, Taiwan government launched a subsidy program for solar hot water heater utilization. This subsidy program is quite successful. The annual sale volume of solar water heater is about 0.5 billion US Dollars. The accumulatod installation area of solar collector is around 0.8 million square meters in 1997. The annual installation colfuctor area is among 69,000 to $93,000 \mathrm{~m}^{2}$ in recent 6 years. Approximate 20,000 families install a solar hot water heater every year. Most of the solar water heaters use an electrical heater installed inside the storage tank as the backup for cloudy days. Expensive running cost as well as additional installation cost of a high power line ( $4 \mathrm{~kW}$ to $6 \mathrm{~kW}$ ) causes a problem

An integral-type solar-assisted heat pump water heater (ISAHP) is thus developed in the present study. It differs from the conventional design (Ito et al, 1997; Chaturvedi et al, 1984; Chaturvedi et al, 1998; O'Dell et al, 1984; Hino, 1995) in that the storage tank and the Rankine cycle unit are integrated together to make a more compact size. A thermosyphon loop is used to transfer the heat from the condenser to the water storage tank. ISAHP can be siraply used as a backup system for solar water heaters or used independently as a solely hot water supply system.

\section{DESIGN OF ISAHP}

The ISAHP consists of a Rankine cycle unit, a collector/evaporator unit which combines the evaporator of the Rankine cycle and the solar collector, and a heat exchanger/condenser unit which combines the condenser of the Rankine cycle and the heater of a thermosyphon loop. Figure 1 shows the schematic of the ISAHP. 
The ISAHP absorbs energy from solar radiation and ambient air simultaneously and then pumps the heat to the storage tank through a Rankine cycle unit. For better reliability and reducing the cost, a heat exchanger/condenser unit is designed with a thermosyphon loop to transfer the heat from the condenser to the water storage tank. The condenser releases condensing heat from the Rankine cycle to the water side of the heat exchanger for producing a natural-circulation flow in the thermosyphon loop.

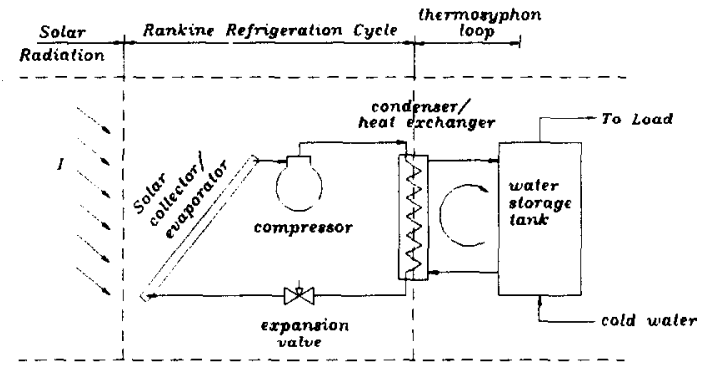

Figure I Schematic diagram of a ISAHP

The performance of an ISAHP is not steady due to the variation of ambient conditions including solar irradiation, wind speed, air temperature and humidity, and raining etc. The design of a Rankine cycle unit for running at unsteady-state conditions is a big challenge. Basically, the evaporation temperature of the Rankine cycle should be controlled at a temperature below the ambient temperature in order to absorb heat from air during cloudy periods. However, it would be close to the ambient temperature during shinny periods. Another design problem is the unbalance between the refrigeration capacity of the compressor and the heat-absorption capacity of the evaporator. This may result in the overheat or shut-down of the compressor.

The solar collector of the ISAHP used in the present study is of tube-in-sheet, unglazed type. The incident solar radiation is absorbed by the collector plate (copper) and transferred to the refrigerant inside the copper tubes (the evaporator of the Rankine cycle). In order to absorb energy from ambient air, no transparent cover is used for the solar collector. The collector plate is divided into 4 parts: $\operatorname{top}(50 \mathrm{~cm} \times$

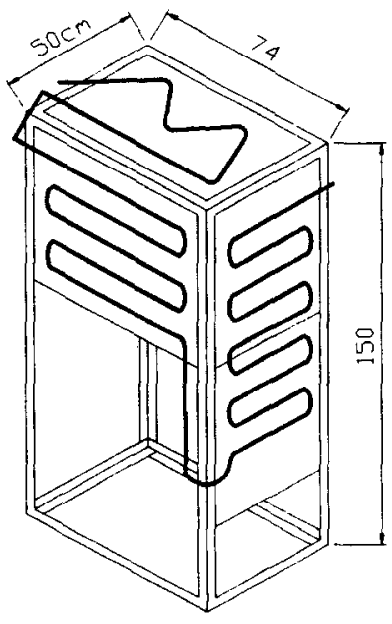

Figure 2 Collector surface of ISAHP

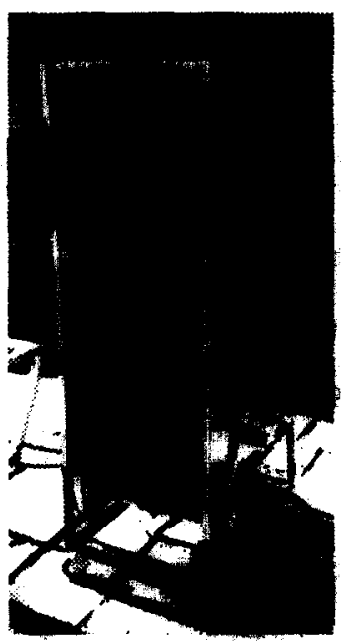

Figure 3 Prototype of ISAHP 
Table 1 Test results of the ISAHP.

\begin{tabular}{|c|c|c|c|c|c|c|c|c|c|c|}
\hline \multicolumn{2}{|c|}{$\begin{array}{c}\text { water temp. } \\
{ }^{\circ} \mathrm{C}\end{array}$} & \multirow{2}{*}{$\begin{array}{c}\text { ambient } \\
\text { temp. } \\
T_{a} \\
{ }^{\circ} \mathrm{C}\end{array}$} & \multirow{2}{*}{$\begin{array}{c}\text { solar } \\
\text { radiation } \\
H_{1} \\
\mathrm{~kJ} \mathrm{m^{2 }} \\
\end{array}$} & \multicolumn{2}{|c|}{$\begin{array}{c}\text { condensing } \\
\text { pressure } \\
M P a\end{array}$} & \multirow{2}{*}{$\begin{array}{c}\text { evaporating } \\
\text { pressure } \\
M P a \\
P_{L} \\
\end{array}$} & \multicolumn{2}{|c|}{$\begin{array}{l}\text { condensing } \\
\text { temp. }{ }^{\circ} \mathrm{C}\end{array}$} & \multirow{2}{*}{$\begin{array}{c}\text { evaporating } \\
\text { temp. }{ }^{\circ} \mathrm{C} \\
T_{e}\end{array}$} & \multirow[b]{2}{*}{$C O P$} \\
\hline $\begin{array}{r}\text { initia } \\
T_{w i}\end{array}$ & $\begin{array}{l}\text { final } \\
T_{\mathrm{w} f}\end{array}$ & & & $\begin{array}{r}\text { initial } \\
P_{H i}\end{array}$ & $\begin{array}{l}\text { final } \\
P_{H f}\end{array}$ & & $\begin{array}{c}\text { initial } \\
T_{c}\end{array}$ & $\begin{array}{l}\text { final } \\
T_{c f} \\
\end{array}$ & & \\
\hline 24.6 & 41.9 & 31.8 & 3950.0 & 1.13 & 1.46 & 0.56 & 44.0 & 54.1 & 19.3 & 3.53 \\
\hline 24.8 & 36.3 & 31. & 3504.0 & 1.6 & 1.20 & & 42.3 & 46.3 & & 3.48 \\
\hline 24.0 & 33.0 & 24.8 & 2636.1 & 1.0 & 1.16 & 0.49 & 41.2 & 45.0 & & 3.56 \\
\hline 24.6 & 35.1 & 31.3 & 1282.5 & 1.0 & 1.18 & 0.49 & 41.9 & 45.6 & 15 & 3.83 \\
\hline 24.5 & 32.6 & 18.3 & 847.4 & 0.90 & 1.02 & 0.3 & 35.5 & 40.4 & 6. & 2.61 \\
\hline 23.6 & 30.5 & 18.3 & 383.0 & 0.9 & 1.00 & & 36.3 & 39.8 & 1. & 2.84 \\
\hline 38.6 & 52.0 & 30.7 & 5581.9 & 1.3 & 1.78 & 0 . & 51.3 & 52.4 & 19. & 2.54 \\
\hline 36.1 & 48.5 & 31.7 & 3255.9 & 1.4 & 1.61 & 0. & 53.9 & 58.2 & 23.2 & 2.81 \\
\hline 36.0 & 46.0 & 30.6 & 1329.4 & 1.40 & 1.55 & 0.5 & 52.4 & 56.6 & 20.4 & 2.55 \\
\hline 36.0 & 44.4 & 18.3 & 602.6 & 1.0 & 1.30 & 0.3 & 41.6 & 49.5 & 6.6 & 1.47 \\
\hline 36.4 & 39.9 & 17.3 & 223.6 & 1.15 & 1.26 & 0.37 & 44.7 & 48.5 & 6.6 & 1.34 \\
\hline
\end{tabular}



Figure 4 Heat exchanger/condenser unit.

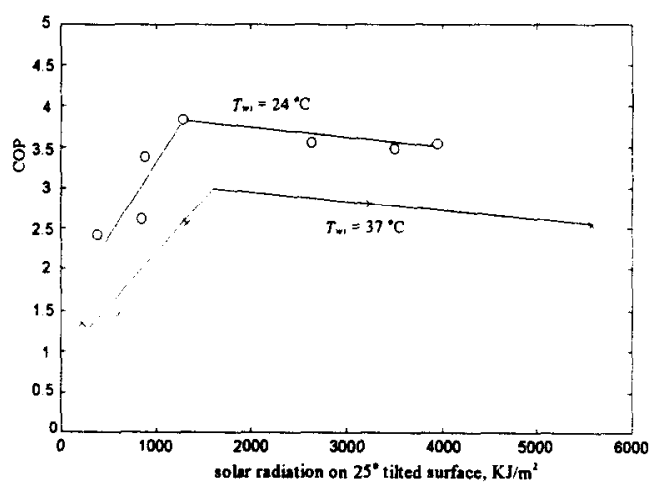

Figure 5 Test result. 
$74 \mathrm{~cm})$, frome $(50 \mathrm{~cm} \times 120 \mathrm{~cm})$ ) and two sides $(50 \times 60 \mathrm{~cm})$ as shown in Figure 2 and Figure 3. The protatype adopts a 120-liter water storage tank and a $110 \mathrm{~V} / 60 \mathrm{~Hz}, 150 \mathrm{~W}$ compressor used in housethold refrigerator. RI334a is used as the woritking fluid. A double-wedll heat exchanger is used as the heat exchangettoordenser unit as shown in Figure 4.

\section{TESTT OF ISAHP}

The ISAFIP is tested under various ambient temperatures and solar irradiation. The temperature variations in water, comdenser and evaporator are recordted. The pressure variations of the Ramkdne cycle unit and the ambient tempiperature and COP are also measured. The COP is defined as the ratio of the actural heat input to the water storage tamk $Q_{H}$ to the electricedl energy input to the compressor $W_{\text {contp }}$ : i.e, $C O P=Q_{K} / W_{\text {comp }}$. The accumwaltat solar radiation energy incident upon a 25 degree tilted surface is recortted during eacth test.

Tests were conducted at two initial water temperatures $\left(24\right.$ and $37^{\circ} \mathrm{C}$, in average). Shown in Table 1 and Figure 5 are the test results. We found that the COP first increases with increasing solar radiation and then reaches a maximum value. After that, COP starts to decrease or saturate. The ambient tomperature has very little influence on the performance of the ISAHP.. It is shown from experiments that the evaporation temperature of the Rankime cycle unit is about 10 to $16^{\circ} \mathrm{C}$ below the ambiemt temperature. This is different from the comclasion of Chaturneedi ef (1998) that the evaperating temperature of the Rankine cycle unit needs to be higher tham the ambient temperature.

The highest comdtensing pressure is $1.78 \mathrm{MPa}\left(62.4^{\circ} \mathrm{C}\right)$ when the solar irradiation has the highest value $\left(5581 \mathrm{k} / \mathrm{V} / \mathrm{m}^{2}\right)$ and the final water temperature reaches $52^{\circ} \mathrm{C}$ with $\mathrm{COP}=2.54$. The highest COP obtained in the present test is 3.83 which occurs at moderate solar irradiation $\left(1282 \mathrm{~kJ} / \mathrm{m}^{3}\right)$ and final comdensing temperature $45.6^{\circ} \mathrm{C}$. The ISAIfiP nuas very well during shinny days. However, the performance is poor at cloudly days (at low solar radiation)) when ISAHIP absortbs heat mainly from the ambient. This may be improved by using an automatic throttling device or adding a bachup evaporator. It is desined to design an ISAHIP with a comstant COP irrespective of the variation of solar radiation. Further stwdy is still underway.

\section{CONCOLISSION}

In the present study,y, we have shown the feasibilitity of an integral tyype solar-assisted heat pumpup water heater (ISAFIIP). ISAHIP integrates the storage tank and the Rankine cycle unit together to make a more compact size. A thenmosyphon loop is used to transfer heat from the comdenser to the water storage tank. Hemce, no circulation pump is requixed. The performance test of a prototype shows that a high COP can be obtained.

\section{RAFAREINGES}

Chaturnedi S.K, Shen J.Y. (1984)). Thermal performance of a direet expansion solar-assisted heat punpp. Solar Energy, 3(20), 155-162.

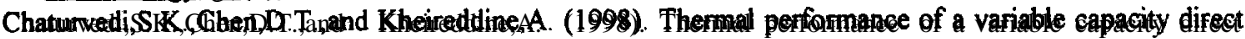
expansion solar-assisted heat pump. Energy Conversion Management, B9, 181-191.

Ito,S,, Miura, $\mathbb{N}$. and Wang/K, (1997)). Performance of a heat pump using direat expansion solar colleatoss. 1997 ISES Solar Wortld Con:sress, August 24-30, 1997. Taejon, Korea.

O'Dell M.P.,Mitthall J.W., Bedkman W.A. (1984). Design method and performance of heat pump with refrigerantffilded solar colloctoss. ASME J, of Solar Eneroy Eng., 8066, 159-164.

Hino, Tostiyduli, (1995)). Performance evaluation of an ambient-neggy heat pump system. ASHRAE Titunsactions: Reseaxch, 10863863393

Acknowlexkmemt - The present studly was supponted by Nationdl Science Council, RQC, Taiwan, thfough Grant Number NSC86-23811-E002-004R. 